Sharia and Justice 



\section{Sharia and Justice}

An Ethical, Legal, Political, and

Cross-Cultural Approach

Edited by

Abbas Poya 
ISBN 978-3-11-045961-6

e-ISBN (PDF) 978-3-11-057459-3

e-ISBN (EPUB) 978-3-11-057359-6

Library of Congress Control Number: 2018941741

Bibliographic information published by the Deutsche Nationalbibliothek The Deutsche Nationalbibliothek lists this publication in the Deutsche Nationalbibliografie; detailed bibliographic data are available on the Internet at http://dnb.dnb.de.

(C) 2018 Walter de Gruyter GmbH, Berlin/Boston Cover image: Abstract colorful oil painting on canvas, Gurgen Bakhshetyan/Shutterstock.com Printing and binding: $\mathrm{CPI}$ books $\mathrm{GmbH}$, Leck

www.degruyter.com 